\title{
South Africa: The early quest for liberty and democracy
}

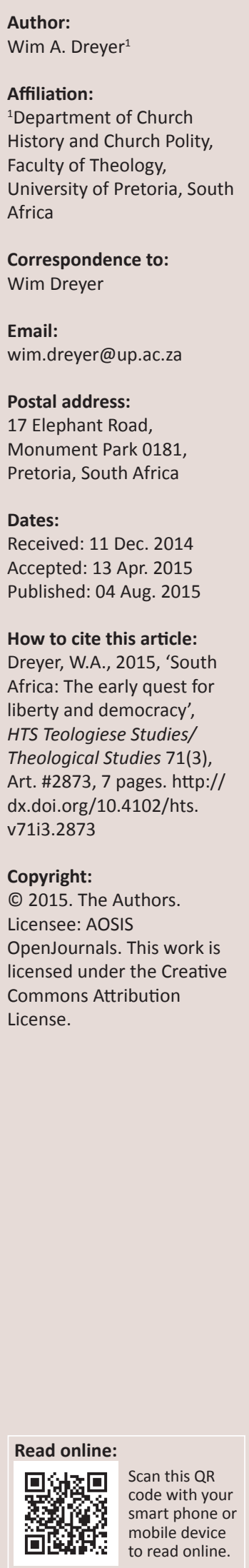

The early quest for liberty and political freedom in South Africa had been influenced by various factors, inter alia political sentiments which originated in Reformed, Huguenot and Patriotten political theory. An analysis of early political ideas indicates that religious sentiments had a significant influence on the development of political ideas. These sentiments and ideas all contributed to a passionate search for freedom, justice and democracy. The different strata of religious and political ideas manifest in a continuous and discontinuous way, giving the impression of fragmented and contorted ideas, but still recognisable in terms of their origins. This contribution is an attempt to identify some of the fragmented and contorted strata of ideas which influenced the early quest for political freedom and the rejection of British colonial rule in South Africa.

\section{Introduction}

The French philosopher Michel Foucault (1972) used the notion of an 'archaeology of knowledge' as a way to reveal discontinuous, fragmented and contorted ideas in history (Beukes 2008:74). Using this notion of an archaeology of knowledge, I will attempt to identify some of the fragmented and contorted strata of ideas which influenced the early (1652-1852) quest for political freedom and the rejection of British colonial rule in South Africa.

Analysis of early political ideas indicates that religious sentiments had a significant influence on the development of political ideas. Whether it could be narrowed down to a 'Calvinistic influence' as proposed by many scholars (Begg 2011; De Gruchy 1986; Giliomee 2004:32-42; Van Jaarsveld 1976:43) is debatable (cf. Britz 2009). More often than not it is unclear when or where these ideas originated. Was it with Calvin, Beza, the French Huguenots, Bullinger or Rousseau? Was it a hybrid of ideas or even completely original? What makes it even more difficult is the lack of direct reference to specific authors.

Despite the complexity of diverse and often opposing political ideas during the early Cape period, there is little doubt that religious beliefs played an important role in the formulation and implementation of political ideas. Reformed ${ }^{1}$ political theory influenced the development of democracy and civil liberty in various countries (Allen 1961:49; Hall 2005; Mosse 1957; TrevorRoper 1967:179-185; Van Schelven 1956:10-11; Witte 2007:xi). The question is: What happened in South Africa?

\section{Into Africa}

In 1652, the United Dutch East India Company (known as the VOC) sent a group of employees to the southern tip of Africa to establish a trading post. The purpose of the settlement was the supply of fresh food and water to the ships of the VOC on route to the East (De Villiers 2012:43-44).

In terms of the VOC charter, the company had the right to appoint a governor and officials who functioned as government at the Cape of Good Hope. When the traders landed in Table Bay on the 6th of April 1652, the first commander of the expedition (Jan van Riebeeck) said a prayer which was recorded in his log or Dagh Register. Van Riebeeck prayed that the Reformed faith (Gereformeerde Christelijke Leere) would spread amongst the inhabitants of this wild and 'brutal' continent (see Dreyer 1999:10-11).

Some of the settlers established themselves as Vryburgers ${ }^{2}$ in different areas of the Cape. Most of them came from Dutch Reformed, German Lutheran or French Huguenot backgrounds

\footnotetext{
1.'Reformed' is used here in a broad sense and should not be regarded as synonymous to 'Calvinistic'. During the early period more than $30 \%$ of the European settlers in the Cape of Good Hope were from Lutheran descent.

2.'Vryburgers' were VOC officials who were released from duty and initially started farming around Cape Town, later moving to outlying
} districts. Slaves were brought from the East and from Africa to work on the farms. 
(De Gruchy 1986:1). They experienced the socio-political turmoil of 17th and 18th centuries personally. Vast areas of Europe were devastated during this period. The Dutch War of Independence, which lasted 80 years, as well as the Religious Wars, which lasted 30 years, ended with the Peace of Westphalia in 1648. In a series of treaties signed at Osnabruck and Münster, the Treaty of Westphalia brought many old political structures to an end and a modern Europe, based on the concept of sovereign states regulated by international law, emerged. In the wake of wartime hardships many Europeans immigrated to the New World, carrying with them very specific political and religious convictions. The Puritans in America and Huguenots in South Africa are classic examples.

In the Cape of Good Hope, liberty and justice became a regular theme in correspondence with the governor and VOC. As early as 1658, only 6 years after the first Europeans arrived in the Cape, fourteen burghers presented the governor with the first of many petitions against the misuse of power and authoritarian control of the VOC over the price the company would pay for produce (Giliomee 2004:1). In 1706, under leadership of Adam Tas and Huguenot Guillaume du Toit, the burghers of Cape Town sent a complaint to the VOC office in Amsterdam requesting a commission of inquiry into the affairs of the officials in the Cape. This was granted in 1707, resulting in burghers charging with horses through the streets of Stellenbosch, firing their guns and shouting 'victory' (De Villiers 2012:46).

A few days later (04 March 1707), Hendrik Biebouw (or Bibault) made a famous remark during a confrontation with Johannes Starrenburg, the magistrate of Stellenbosch: 'Ik ben een Africaander! Ik zal, nog wil niet zwijgen ...' (Giliomee 2004:19; Van Jaarsveld 1959:15). This is the first official record of a European, under threat of deportation, who identified himself as someone born in Africa and with no desire to return to Europe. His protestations did not help much: The 1708 census shows an inscription behind his name 'weg', meaning 'gone'. He was either deported or disappeared into the hinterland.

In 1752, with the centenary of the Cape settlement, the Rev. Petrus van der Spuy led a commemorative service in which he referred to the colonists in the Cape of Good Hope as a volk (a people or a new nation distinguishable from other nations) and the settlement in the Cape of Good Hope as a volksplanting under the providence of God. During the 18th century colonists born in the Cape of Good Hope commonly referred to themselves as 'Africaanders', people of Africa and not of Europe (cf. Giliomee 2004:18-42).

In the following paragraphs a short overview is given of individuals, events and institutions which had some bearing on the development of political ideas during the early Cape period. Different strata of political ideas can be traced back to these events or institutions.

\section{Reformed stratum}

During 1651, one year before Van Riebeeck established the trading post at the Cape of Good Hope, the Grootte Vergadering convened in The Hague. Seven Dutch provinces reached an agreement on the unification of the provinces, military structures and religious matters. The Reformed faith, as articulated during the Synod of Dort (1618-1619), became the dominant religion protected by the monarchy and States General. As a result, the Reformed church ${ }^{3}$ was also supported by the VOC (see Dreyer 1999:9-24; Pauw 2007:60-62; Spoelstra 1907). The church in Cape Town (as well as congregations established later) fell under the jurisdiction of the governor as well as the Classis of Amsterdam and Synod of Northern Holland. In church matters the Canons of Dort, as well as Van Diemen's church order, were used as guidelines in conjunction with the regulations of the VOC (Booyens 1965:13).

The first Reformed minister in Cape Town was the Rev. Joannes van Arckel, who arrived in 1665. He died after 1 year, but in that short period established a congregation, ordained elders and deacons, established a church register and preached on a regular basis. The remuneration of ministers came from the VOC. Between 1665 and 1795 only six Reformed congregations were established, covering vast areas of Southern Africa.

Census documents from 1770 show that $90 \%$ of the female population of Stellenbosch were baptised and confirmed as members of the Reformed church, while only $30 \%$ of the male population were officially confirmed. This was due to the migratory nature of farming and herding livestock in remote areas (Giliomee 2004:33).

The general public came from diverse backgrounds and had little theoretical knowledge of Reformed political theory. There is some indication that few of the more educated individuals read Calvin, Bullinger and other Reformed authors. One can also assume that those individuals who were actively involved in the Reformed congregations would have been influenced by Reformed preaching and catechesis. They would have had a certain knowledge of the Reformed confessions. This would also impact on the development of political ideas (Beyers 1967:289; Pont 1988:51-60; Storm 1989:21; Strauss 1986:1; Van Jaarsveld 1976:43).

Research had been done on printed matter and books which were in circulation during this period (cf. Van Zijl 1992). According to Van Zijl, the most common reading materials were the following:

- The Dutch Statenbijbel with notes which interpreted biblical passages from a Reformed perspective. The early pioneers maintained daily devotions with Scripture reading and prayers, which in the vernacular was called Boekevat. It was typical of Boekevat to be led

3.In this contribution 'church' is written without capitalisation because it does not refer to a specific denomination. The concept of a 'denomination' is a late development and did not exist at the time. 
by the head of the family (the father or mother) with the family sitting around the dining table and all the slaves and labourers standing or sitting on the floor (Begg 2011:78-85).

- The Reformed confessions were bound into the Bible and read on a regular basis.

- Hymnals of Sluyter, Van Lodenstein and Groenewegen were used during devotions.

- Sermons of Smijtegeld, Schortinghuis, Costerus and especially Heinrich Bullinger were well known, much loved and read on Sundays by the head of the family to all present.

- Hellenbroek's Kort Begrip der Christelijke Religie and the Heidelberg Catechism of Ursinus were used to educate the children. The importance of the Heidelberg Catechism in South Africa cannot be underestimated. The first report on the Heidelberg Catechism in South Africa dates from 1655. Ziekentrooster ${ }^{4}$ Wijlant reports in his diary that during his visit to the Cape of Good Hope he regularly read from 'Ursinus', meaning Het Schatboek der Verklaringen van de Heidelbergse Catechismus by David Pareus and translated by Festus Hommius in 1602 as well as sermons on the Catechism, published by Lansbergius in 1616 (cf. Oberholzer 1986:7-8). The use of the Heidelberg Catechism for catechesis and preaching were continued by the ziekentroosters until the beginning of the 19th century, a period during which very few ordained ministers were active on the Cape frontier and most ecclesial duties were performed by elders, deacons and especially ziekentroosters.

- Wilhelmus á Brakel (1981) was well known amongst the burghers (Strauss 1986:1-3). Several old copies of his Redelijke Godsdienst are still to be seen in archives.

These documents did not only guide and influence religious sentiments, but also political ideas. One example would be their knowledge of Article 36 of the Belgic Confession, which reads as follows according to the official translation of the Reformed Church of America ${ }^{5}$ :

We believe that because of the depravity of the human race, our good God has ordained kings, princes, and civil officers. God wants the world to be governed by laws and policies so that human lawlessness may be restrained and that everything may be conducted in good order among human beings. For that purpose God has placed the sword in the hands of the government, to punish evil people and protect the good. And the government's task is not limited to caring for and watching over the public domain, but extends also to upholding the sacred ministry, with a view to removing and destroying all idolatry and false worship of the Antichrist; to promoting the kingdom of Jesus Christ; and to furthering the preaching of the gospel everywhere; to the end that God may be honoured and served by everyone, as he requires in his Word.

4.Ziekentroosters' were lay people trained to minister to sailors on the merchant fleet of the VOC, which had a very high mortality rate. When the 'ziekentroosters' were in port, or if they settled in colonies, they continued in port, or if they settled in colonies, they continued their ministry in frontier areas 'consoling the sick'. Heidelberg Catechism Sunday 1 starts with the very question of our 'only consolation in life and in death ...'

5.To be found at https://www.rca.org/resources/belgic-confession.
This formulation reflects typical 16th century Reformed theology and political theory. Being part of the confession of the Reformed church, it was taken very seriously and at various stages the early pioneers tried to establish political structures in accordance with this article. This will be discussed later on in this contribution.

\section{French Huguenot stratum}

An important addition to the number of colonists and the Reformed church was the arrival of French Huguenots who had to leave France and immigrated to the Cape of Good Hope. The first Huguenots arrived in 1671. By the turn of the century more than two hundred established themselves in the vicinity of Franschhoek. It seems like an insignificant number, but if one keeps in mind that the colonists at the Cape numbered less than a thousand, it means that the Huguenots made up $20 \%$ of the colonists. The French Huguenots were politically very aware, resulting in their prolonged struggle against the absolute power of the king. Could it be surmised that this political awareness would also surface in the Cape of Good Hope? South African historiography (cf. Britz 2009) is not in agreement on this matter, mostly due to the scarcity of primary sources.

However, if one applies Foucault's archaeological approach, one could assume that some remnant of Huguenot political theory would be present in the Cape as a substratum in political consciousness, although not expressis verbis. Continuity and discontinuity should be assumed. Foucault (1972:4-6; see also Beukes 2008:75-76) formulates it as follows:

Beneath the great continuities of thought ... one is now trying to detect the incidence of interruptions. Interruptions whose status and nature vary considerably ... they suspend the continuous accumulation of knowledge, interrupt its slow development, and force it to enter a new time ... they direct historical analysis away from the search for silent beginnings and the never-ending tracing-back to the original precursors, towards the search for a new type of rationality and its various affects ...; they show that the history of a concept is not wholly and entirely that of its progressive refinement, its continuously increasing rationality, its abstraction gradient, but that of its various fields of constitution and validity, that of its successive rules of use, that of the many theoretical contexts in which it developed and matured ... The use of concepts of discontinuity, rupture, threshold, limit, series and transformation present all conventional historical analysis not only with questions of procedure, but with theoretical problems. Tracing the development and progressive refinement of ideas in any particular field is therefore extremely difficult, too difficult in fact, for conventional historiography to be of service. (Beukes 2008:75-76)

But what were the political principles of the Huguenots in France? During 1463, Louis XI founded the University of Bourges with the specific goal to establish the rational grounds for an absolutist monarchy (Wendel 1963:24). Absolutism reached its zenith during the 17th century with Louis XIV (1638-1715) who claimed 'l'état, c'est moi'. Despite studying at the University of Bourges during 1529, Calvin 
was opposed to absolutism as is clear in his commentary on Seneca's De Clementia (Calvin [1532] 1998). Calvin argued that kings should govern in accordance with God's law, humanity and justice. This implies that the king's power is limited by moral virtue, Christian love and God himself.

After the massacre of Huguenots in Paris (23-24 August 1572), outraged French patriots such as Theodor Beza (Calvin's successor in Geneva), Francois Hotman (Calvin's secretary and professor of law), Philippe de Mornay Du Plessis (lawyer and Huguenot leader) as well as Hubert Languet (French lawyer, diplomat, personal friend of Melanchthon, and Calvinist) radicalised their struggle against tyranny and their quest for liberty and justice (Allen 1961:302-331). They made their political views known through various publications. Beza's De iure magistratuum in subditos (Beza [1574] 1956) was cited in English, French, Dutch, German and Hungarian publications. During the first years, 88 editions of the De iure magistratuum appeared. In England, two editions per year had to be printed to keep up with the demand. Most editions were printed together with other documents such as the influential Vindiciae contra tyrannos, published under the pseudonym Junius Brutus ([1579] 1972) and Machiavelli's Il Principe, which was in complete contradiction to the De iure magistratuum (Van Schelven 1956:3). The Vindiciae was probably the work of Philippe de Mornay. Hotman's Franco Gallia was also an influential document which pleaded for a representative and idealised form of Protestant government.

The fundamental question these documents asked concerned the nature of political authority and the extent of the obedience due to it (Allen 1961:313). Some of their views, especially the right to resist an unjust ruler, were in direct contradiction to those of Calvin and more in line with William of Occam and Nicholas of Cusa, who argued that the rulers can only rule by consent of their subjects. Important themes discussed in these documents (Allen 1961:318; Beza [1574] 1956:25-35) were inter alia:

- the late medieval notion of rex sub lege

- the limitation of a ruler's rights

- the sovereignty of the people

- the right of the people to reject a ruler

- a ruler receives his office from God, but his authority from the people, on condition that government is done to the benefit of the people

- all rulers should govern to the benefit of the people

- rulers exist for the benefit of the people and not vice versa

- the office of ruler is conferred only conditionally by God; the condition being that he would govern justly, wisely and to the benefit of all subjects

- a covenantal relationship exists between God, people and the king.

Again, it should be assumed that people who were subjected to severe political oppression by the French king and forced to leave their fatherland would have some political awareness and carry with them some political ideas.

\section{The Patriotten stratum}

When we unearth the layers of socio-political ideas and sentiments during the late 18th and early 19th centuries, the prominence of the Cape Patriotten ${ }^{6}$ movement is quite evident. Patriotten ideas had a significant influence on the development of a unique political paradigm. In the minds of the burghers the French Revolution's slogan Liberty, Equality and Fraternity became a 'true Biblical principle' (ZAR Volksraad, Memo to Parliament R1395/57; R1400/57; $\mathrm{R} 1425 / 57)^{7}$.

The burghers' political aspirations were inflamed by local conditions and economic hardship, as well as political developments in Europe, especially the Patriotten movement in the Netherlands. The Patriotten notion of man, his world and society was built on the views of Thomas Hobbes, John Locke, David Hume, Francis Hutchinson, Joseph Priestly, Adam Smith, Richard Price, Samuel Pufendorf, Christian Thomasius and Jean Jacques Rousseau. Pamphlets, letters and books which propagated Patriotten notions circulated among the Cape burghers (Beyers 1967:211). These documents supplied the terminology, language and direction to the burghers' resistance and rejection of the VOC's misuse of power, nepotism and fraud.

The Patriotten movement was not only influenced by the French Revolution, but also the American Revolution and Declaration of Independence (Giliomee 2004:42). The American quest for liberty and democracy was idealised in many publications. The American revolutionaries were also known as 'patriots'. The Cape Patriotten focused their attention on local issues, especially the continuing inclination of VOC officials to regard the burghers as subject to the absolute power of the VOC. The VOC could use their power to 'press gang' burghers into the service of the VOC and send them away to other posts, especially those who were rebellious - as was the case with C.H. Buitendagh (Giliomee 2004:43). The VOC exercised their right of deportation, which led to secret meetings and anonymous pamphlets rejecting the absolute powers of the VOC.

The Cape Patriotten sent many petitions to the Netherlands as well as a delegation which they called the 'representatives of the whole burgher state' (Burgerstaat) (Giliomee 2004:43-44). The delegation met with the States General as well as the Dutch Patriotten movement. They presented their grievances and demands, including the misuse of power by VOC officials, self-enrichment by corrupt officials and seven seats in the Politieke Raad. The Lords XVII rejected the burghers' petition, after which they continued their petitions and sent another delegation.

\footnotetext{
6.The conservatism of the princes of Orange, the Enlightenment as well as the French and Ams (1787) which became know political movemetriot in the Netherlands (approx. 1780-1787) which became known as the Patriot Movement, or Patriotten. For a more complete discussion and literature, see Prak (1991)

7.Volksraad Zuid-Afrikaansche Republiek, 1853-1854, 'Memories', SA Argiefstukke Transvaal no. 2/3. Government Press, Parow.
} 
In 1778 an anonymous pamphlet titled De magt en vrijheden eener Burgerlijke Maatschappfj, verdedigt door der vernaamste Regtsgeleerden, opgedragen aan het oordeel der Caabsche Burgery ${ }^{8}$ was secretly circulated amongst the burghers. According to Beyers (1967:214) the author was a prominent Dutch lawyer, Elie Luzac. The basic premise of Luzac's pamphlet is that every man is responsible for his own and his neighbour's welfare, as well as society as a whole. This moral law has its roots in Pufendorf's De hominis et civis officiis iuxta legem naturalem as well as the theories of Hugo Grotius, John Locke and Thomas Hobbes. Luzac touches on subjects such as civil liberty, the priority of het volk [the people] in relation to government, slavery, freedom of the press and freedom of religion. The pamphlet was regarded as of such a revolutionary nature that the governor immediately banned it.

These ideas became very influential and dominant. Dissatisfaction with VOC governance intensified to such an extent that the burghers in June 1795 established the Republic of Swellendam and the Republic of Graaff-Reinet. Different aspects of Patriotten political theory, such as the separation of church and state (contrary to typical Calvinist theory), as well as the separation of judicial and legislative powers were important to the Cape Patriotten. The citizens of Swellendam and Graaff-Reinet felt so strongly about these principles that on June 16 a large number of them marched to the government offices and demanded the resignation of officials such as BJ Burger and J Jacobs, respectively elder and deacon in the church (Beyers 1967:241). These events took place under the battle cry of the French Revolution: Equality, liberty and fraternity! The republics were shortlived, as during the same year the first British occupation of the Cape of Good Hope took place and the Cape militia had to surrender to superior military forces at the Battle of Muizenberg (07 August 1795).

The British occupation of the Cape of Good Hope was of strategic importance in light of the on-going Napoleonic War. It also affected the end of the VOC and its role in governing the Cape of Good Hope. In 1802 the Peace of Amiens was concluded, and although it lasted just 1 year, the Cape was returned to the Netherlands. After Britain withdrew from Cape Town, the States General of the Netherlands sent J.W. Jansens J.A. De Mist as administrators to Cape Town. They arrived in February 1803).

De Mist is important in our discussion of the Patriotten. De Mist had a strong inclination towards the Patriotten movement. He was commissioned to reorganise the administration and governmental administration at the Cape (Van Zyl 1975:113). In 1806 the British forces again occupied Cape Town, this time permanently. As a result, De Mist returned to the Netherlands after just 3 years, but his influence exceeds the brevity of his stay in Cape Town. After the demise of the VOC, the end of the first British occupation and amid changing political views, new political forms and arrangements were needed in the Cape of Good Hope. Political, religious and educational principles had to be formulated and implemented (Murray 1962:11). De Mist was the man who gave some direction to governmental institutions.

De Mist was an extremely capable administrator. He was a well-educated lawyer, experienced politician, administrator and diplomat. In the Netherlands he was involved in the process of separation between church and state and served on various parliamentary committees. In 1801 he presented to the Council of Asian Affairs a memorandum on principles of administration at the Cape.

This memorandum was so thorough that he was sent to the Cape as administrator. At the Cape, he worked at an enormous pace to implement his political ideas (cf. Murray 1962 for an overview of De Mist's contribution). De Mist's background is of considerable importance. In 1800 he was appointed as Grand Master of the Free Masons and he opened the Freemasons Lodge in Cape Town in 1803. In his inaugural speech (delivered with his appointment as Grand Master) the influence of the Patriotten movement became clear. His point of departure was J Rousseau's thought. He interpreted the slogan freedom, equality and fraternity within the Dutch context. His speech reflects a strong religious inclination, but in a moralistic way typical of the Enlightenment (Murray 1962:14). De Mist was moderate in his thinking and has never supported the extreme forms of revolutionary politics.

De Mist was trained in traditional Dutch law (Murray 1962:17). He never abandoned the old political principles completely. Some of the Reformed ideas of the Vindiciae counter tyrannos are still to be found in his formulations. De Mist, as the Vindiciae, held on to 'the people' as the core of political thought. He regarded the black tribes and white settlers at the Cape as nations with the basic rights of all nations. He defined these nations' relationship with the Netherlands in contractual terms (Murray 1962:24). He maintained pluralism as a basic point of departure, which meant that the Cape would enter into a confederal and contractual relationship with the Netherlands.

Other principles which De Mist implemented are the following (Murray 1962:105-122):

Rule of law: De Mist regarded rule of law as the cornerstone of good governance and justice. In his exposition of this principle he follows the pattern of the Vindiciae contra tyrannos. In his correspondence with the hot-headed burghers of Swellendam and Graaff-Reinet, he emphasised the importance of rule of law. For the first time in the history of the Cape, legal principles formed the basis of governance. It is remarkable that De Mist chose to use Reformed political theory to give substance to his argumentation. He finds in Reformed political theory the language to describe the balance between the rights and responsibilities of the government as well as the people (Murray 1962:106-108). 
Covenant: In his exposition of the relationship between the Cape and the Netherlands, De Mist makes use of the ancient foedus principle (Murray 1962:108-112). According to this principle, society consists of various corporations (government, church, people, arts and business) which are all interrelated, responsible and joined together. De Mist is of the opinion that the objective of government is not to control or manipulate society through political power or persecution, but to protect the established rights and freedom of the people. He rejects a state or government with absolute power and maintains a commonwealth based on the recognition of diversity.

Pluralism: In his management of the Koi tribes, De Mist followed a policy which could be described as 'pluralistic'. It meant that the tribes were given a certain independence and recognition of tribal heads. Relations with the tribes were regulated by means of contracts and agreements. In this he followed a principle formulated by Hugo Grotius (suos reges, suam rempublicam; suas leges, sua iura). It recognises the rights and sovereignty of nations within specific geographical areas. The same principle was utilised for the establishment of local governing bodies or 'heemrade' (Murray 1962:112-120).

It is quite obvious how some of these principles influenced the political development of South Africa.

\section{The Great Trek}

From 1836 onwards, many burghers rejected British rule and left the Cape Colony by emigrating north of the Gariep River border. This emigration became known as the Great Trek' The first leader of the Great Trek was Piet Retief. His greatgrandfather was the Huguenot François Retif, from Mer near Blois, who settled in the Cape in 1689.

During the Great Trek leaders like Piet Retief, Gerrit Maritz and Kootjie Burger upheld the republican-democratic principles with utmost conviction. The Great Trek is regarded by many as the first freedom movement and rejection of colonial rule on the African continent (Duvenage 1987:13; Van der Watt 1977:20; Van Jaarsveld 1974:7). In Retief's Manifesto, as published in the Graham's Town Journal on February 2, 1837 we read: 'We quit this colony under the full assurance that the British Government has nothing more to require of us, and will allow us to govern ourselves without its interference in future' (cf. Van Jaarsveld 1971:55). This Manifesto could be viewed as a unilateral declaration of independence.

On 02 December, 1836 the emigrants elected a Representative Council (Raad van Representanten) with the mandate to handle all military, legislative and judicial affairs. The British Government and colonial authorities regarded the emigrants as British subjects and the Great Trek as an act of rebellion, and refused to recognise the new 'sovereign state' to the North.

9.The Great Trek was a movement of Dutch-speaking colonists up into the interio of Southern Africa in search of land where they could establish their own republic, independent of British rule.
The emigrants consistently chose to govern themselves within a republican form of government, as with the establishment of the Republics of Swellendam and GraaffReinet in 1795. They were passionate about their freedom and the right to govern themselves in a system where the people have the final say. It was an extreme form of democratic and republican government, because all decisions were taken at meetings where all adult males had a vote (Gey van Pittius 1936:7). Political principles such as democracy, rule of law, justice, freedom and government by and for the people are present in many documents. D.W. Krüger (1963:86) comes to the conclusion that, in the minds of the Cape burghers republican and Reformed political ideas attained some form of fusion.

One example of such a fusion is to be found in the oath which Retief took after he had been elected as the first governor of the emigrants who established themselves outside the Cape Colony and British rule:

Ik Pieter Retief, door de volkstem wettig gekozen ... zwere tans ... dat ik ... de Christelljke Geloofsbelijdenis, naar de inhoud van Artikel 36, met de aankleving van dezelve, de katechismus en de Liturgieen, der Nederdultsch Gereformeerde Kerk zal protekteren en beschermen, en dat ek in mijn Goevernement geen beampte zal toelaten in de Kerkelike Burgerlike Regering, als die lidmaten zijn der voormelde Gereformeerde Kerk. (cf. Storm 1989:47)

In this oath of office the theocratic and organic unity between church, government and people, so typical of Reformed thinking (Haitjema 1957:1137) becomes clear. It is remarkable that the oath mentions in one sentence the voice of the people, Article 36 of the Belgic Confession and the Heidelberg Catechism. As work on the constitution progressed, the interchangeable use of democratic and Reformed principles continued unabated, for instance in Article 14 of the Second Constitution, signed 20 October 1838 (Preller 1924: XIII) ${ }^{10}$.

We also find the Reformed influence in a document such as the Gelofte (Covenant), which the burghers entered into before the Battle of Blood River (16 December 1838). It reflects Wilhelmus à Brakel's (1981:516-619) understanding of the covenant as discussed in his Redelijke Godsdienst II / XXXVII.

In 1852 the British Government changed their policy towards the emigrants. At the Sand River Convention they signed a document with which the sovereignty of the emigrants and status of the Representative Council (Volksraad) was acknowledged. In terms of the Constitution of the ZuidAfrikaansche Republiek (ZAR), which was approved on 05 January 1857 and published officially in 1858 (Volksraad van die ZAR 1858:382), the Nederduitsch Hervormde Kerk became the church of the state, and the Reformed confessions entrenched in the Constitution, for example Article 20:

'... de Nederduitsch-Hervormde Kerk zal de kerk van de Staat zyn') and Article 23 ('Het volk wil zyne Nederduitsch

10.The archives of the emigrants were collected under commission of the SA .The archives of the emigrants were collected under commission of the SA
Akademie vir Wetenskap en Kuns by Preller, G.S., 1924, Voortrekker Wetgewing. Notule van die Natalse Volksraad 1839-1845, JL van Schaik Bpk., Pretoria. 
Hervormde godsdienst, zoo als die in de jaren 1618 en 1619 door de synode te Dordrecht is vasgesteld, behouden').

Most of the articles of the Constitution start with the phrase 'Het volk wil', meaning 'it is the will of the people'. This was a typical formulation used by the Patriotten. Democratic principles, the liberty of the people, the protection of the Reformed church and the authority of the Reformed confessions became part of the ZAR Constitution on grounds of the people's will. For many of the burghers the people's will was indeed God's will. Beyers (1967:237-298) devotes a whole section of his research to the notion of vox populi, vox Dei. A later president of the ZAR, Paul Kruger, often spoke of the people's will as God's will. This single phrase, more than any other, exemplifies the integration of democratic and religious (Reformed) ideas.

The quest for liberty did not end with the Great Trek. It continued into the 20th century. It often resulted in military conflict, as in the Battle of Congella (1842); the Battle of Boomplaats (1848); the First Anglo-Boer War (1880-1881); the Second Anglo-Boer War (1899-1902) and the Rebellion (1914).

\section{Conclusions}

It is my contention that the early quest for liberty and political freedom in South Africa had been influenced by various factors, inter alia political sentiments which originated in Reformed, Huguenot and Patriotten political theory. There are of course more, such as their understanding of the Old Testament, Calvinistic church polity and physical circumstances. These sentiments and ideas all contributed to an idealisation of political freedom. The different strata of religious and political ideas manifest in a continuous and discontinuous way, giving the impression of fragmented and contorted ideas but still recognisable in terms of their origins.

\section{Acknowledgements Competing interests}

The author declares that he has no financial or personal relationships which may have inappropriately influenced him in writing this article.

\section{References}

À Brakel, W., 1981, Redelijke godsdienst, Three parts, 6th edn., B.V. Uitgeverij "De Banier", Utrecht.

Allen, J.W., 1961, A history of political thought in the sixteenth century, Methuen, London.

Begg, M.H., 2011, 'A Weberian analysis of Afrikaner Calvinism and the spirit of capitalism', PhD dissertation in the Faculty of Arts and Social Science, University of Stellenbosch.

Beukes, J., 2008, 'Voices carry: An archaeology of the Hervormd approach', HTS Teologiese Studies/Theological Studies 64(1), 73-109. http://dx.doi.org/10.4102/ hts.v64i1.4

Beyers, C., 1967, Die Kaapse Patriotte gedurende die laaste kwart van die agtiende eeu en die voortlewing van hulle denkbeelde, JL van Schaik Bpk., Pretoria.
Beza, T., [1574] 1956, De iure magistratuum in subditos, et officio subditorum erga magistratus, ed. A.H. Murray, transl. H.L. Gonin, HAUM, Cape Town/Pretoria.

Booyens, B., 1965, 'Kerk en Staat 1795-1843', in Argiefjaarboek vir SA Geskiedenis, Jg. 28/2, Government Printers, Cape Town.

Britz, D., 2009, 'The French refugees in 20th century South African Historiography', Studia Historiae Ecclesiae XXV(1), 121-153.

Brutus, J., [1579] 1972, Vindiciae contra tyrannos, transl. H.J. Laski, Burt Franklin, New York, NY.

Calvin, J., [1532] 1998, Commentary on Seneca's De Clementia,The Ages Digital Library, Albany, NY.

De Gruchy, J.W., 1986, The church struggle in South Africa, William B. Eerdmans Publishing Company, Grand Rapids, MI.

De Villiers, J., 2012, 'Die Nederlandse era aan die Kaap, 1652-1806', in F. Pretorius (red.), Geskiedenis van Suid-Afrika. Van voortye tot vandag, bl. 39-62, Tafelberg Uitgewers, Kaapstad.

Dreyer, W.A., 1999, Nederduitsch Hervormde Kerk van Afrika, 1652-1902, Kital, Pretoria.

Duvenage, G.D.J., 1987, Die Groot Trek, Deel II. Die Manifes, Afrikanervolkswag, Pretoria.

Foucault, M., 1972, The archaeology of knowledge, transl. S. Smith, Tavistock, London.

Gey van Pittius, E.F.W., 1936, Volksregering met besondere verwysing na Suid-Afrika, Wallachs, Pretoria.

Giliomee, H., 2004, Die Afrikaners. 'n Biografie, Tafelberg Uitgewers Beperk, Kaapstad. Haitjema, J.Th, 1957, 'Calvijn en de Calvinisme', in J. Waterink (red.), Cultuurgeschiedenis van het Christendom, pp. 1132-1175, Elsevier, Amsterdam/Brussel.

Hall, D.W., 2005, The Genevan reformation and the American founding, The Rowman and Littlefied Publishing Group (Lexington Books), Lanham, MD.

Krüger, D.W., 1963, Paul Kruger, Deel II, Afrikaanse Pers Boekhandel, Johannesburg.

Mosse, G.L., 1957, Calvinism. Authoritarian or democratic? Rinehart and Company, New York, NY.

Murray, A.H., 1962, The political philosophy of J.A. De Mist, HAUM, Cape Town/ Pretoria.

Oberholzer, J.P., 1986, Die Heidelbergse Kategismus, Kital, Pretoria.

Pauw, J.C., 2007, 'Anti-Apartheid theology in the Dutch reformed family of Churches. A depth hermeneutical analysis', Akademisch proefskrift, Vrije Universiteit Amsterdam.

Pont, A.D., 1988, 'Die Gelofte van 1838 - 'n poging om die teologiese agtergrond te peil', in A.D. Pont (red.), Die Gelofte van 1838, bl. 38-53, Kital, Pretoria,

Prak, M., 1991, 'Citizen radicalism and democracy in the Dutch Republic: The Patriot Movement of the 1780s', Theory and Society 20(1), 73-102. http://dx.doi. org/10.1007/BF00160734

Preller, G.S., 1924, Voortrekker Wetgewing, Van Schaik, Pretoria.

Spoelstra, C., 1907, Bouwstoffen der Nederduitsch-Gereformeerde Kerken in ZuidAfrika, Hollandsch-Afrikaansche Uitgevers-Maatschappij, Amsterdam.

Storm, J.M.G., 1989, Die Voortrekkerkerk 1836-1853, Kital, Pretoria.

Strauss, L.J., 1986, Ekklesiologie van W á Brakel: 'n Poging om die grondslag van die kerkbegrip van die Voortrekkers vas te stel, The Author, Pretoria.

Trevor-Roper, H., 1967, The crisis of the seventeenth century, Liberty Fund, Indianapolis, MN.

Van der Watt, P.B., 1977, Die Nederduitse Gereformeerde Kerk 1834-1866, NG Kerkboekhandel, Pretoria.

Van Jaarsveld, F.A., 1959, Die ontwaking van die Afrikaanse nasionale bewussyn 1868 1881, Voortrekkerpers, Johannesburg.

Van Jaarsveld, F.A., 1971, 100 Basiese dokumente by die studie van die Suid-Afrikaanse geskiedenis 1648-1961, Nasou Beperk, Kaapstad.

Van Jaarsveld, F.A., 1974, Geskiedkundige verkenninge, JL van Schaik, Pretoria.

Van Jaarsveld, F.A., 1976, VanVan Riebeeck tot Vorster, 1652-1974, Tweede Uitgawe, Perskor Uitgewery, Johannesburg.

Van Schelven, A.A., 1956, 'Introduction', in Beza, T., [1574] 1956, 'De iure magistratuum in subditos, et officio subditorum erga magistratus', p. 3-12, ed. Murray A.H., transl. Gonin H.L., HAUM, Cape Town/ Pretoria.

Van Zijl, W.J., 1992, Van skeepskis tot wakis tot boekrak, Lux Verbi, Kaapstad.

Van Zyl, M.C., 1975, 'Oorgang, 1795-1806', in C.F.J. Muller (red.), 500 Jaar SuidAfrikaanse Geskiedenis, bl. 104-119, Academica, Pretoria.

Volksraad Zuid-Afrikaansche Republiek, 1853-1854, 'Memories', SA Argiefstukke Transvaal no. 2/3. Government Press, Parow.

Volksraad van die ZAR, 1858, SA Argiefstukke Transvaal no. 3:382, Government Press, Parow.

Wendel, F., 1963, Calvin, transl. P. Mairet, William Collins Sons \& Co, London.

Witte, J., 2007, The Reformation of rights. Law, religion and human rights in early Calvinism, Cambridge University Press, Cambridge. 